\title{
Effect of Preparation Conditions on the Catalytic Activity of CuMnOx Catalysts for CO Oxidation
}

\author{
Subhashish Dey ${ }^{1, *}$, Ganesh Chandra Dhal ${ }^{1}$, Devendra Mohan${ }^{1}$, Ram Prasad $^{2}$ \\ ${ }^{1}$ Department of Civil Engineering, IIT (BHU) Varanasi, India \\ ${ }_{2}^{2}$ Department of Chemical Engineering and Technology, IIT (BHU) Varanasi, India
}

Received: 9th January 2017; Revised: 24th May 2017; Accepted: 25th May 2017; Available online: 27th October 2017; Published regularly: December 2017

\section{Abstract}

The hopcalite $\left(\mathrm{CuMnO}_{\mathrm{x}}\right)$ catalyst is a well-known catalyst for oxidation of $\mathrm{CO}$ at ambient temperature. It has prepared by co-precipitation method and the preparation parameters were like Copper/Manganese $(\mathrm{Cu}: \mathrm{Mn})$ molar ratios, drying temperature, drying time, calcination temperature and calcination time has an influence on activity of the resultant catalyst. The activity of the catalyst was measured in flowing air calcinations (FAC) conditions. The reaction temperature was increased from ambient to a higher value at which complete oxidation of $\mathrm{CO}$ was achieved. The particle size, weight of catalyst and $\mathrm{CO}$ flow rate in the air were also influenced by the activity of the catalyst for CO oxidation. The characterizations of the catalysts were done by several techniques like XRD, FTIR, BET, SEM-EDX and XPS. These results were interpreted in terms of the structure of the active catalyst. The main aim of this paper was to identify the optimum preparation conditions of $\mathrm{CuMnO}_{\mathrm{x}}$ catalyst with respect to the performance of catalyst for CO oxidation. Copyright (C) 2017 BCREC Group. All rights reserved

Keywords: Carbon monoxide; $\mathrm{CuMnO}_{\mathrm{x}}$ catalyst; Co-precipitation; Drying temperature; Calcination; Activity measurement

How to Cite: Dey, S., Dhal, G.C., Mohan, D., Prasad, R. (2017). Effect of Preparation Conditions on the Catalytic Activity of $\mathrm{CuMnO}_{\mathrm{x}}$ Catalysts for CO Oxidation. Bulletin of Chemical Reaction Engineering \& Catalysis, 12 (3): 431-451 (doi:10.9767/bcrec.12.3.900.437-451)

Permalink/DOI: https://doi.org/10.9767/bcrec.12.3.900.437-451

\section{Introduction}

Carbon monoxide (CO) is well known as a silent killer (21 $1^{\text {st }}$ Century) because it has no color, no smell, and no order. The CO is produced by incomplete combustion of any carbon-containing fuel (Coal, Petroleum, natural gas, etc.) [1-2]. When CO enters into a human body by a respiration processes it combined with hemoglobin presence in a blood cell and converted into carboxyhemoglobin $(\mathrm{CoHb})$. The binding ability of

* Corresponding Author.

E-mail: subhasdey633@gmail.com (Dey, S.)
CO with hemoglobin is 200 times greater than oxygen [3]. The most common symptom of $\mathrm{CO}$ poisoning is a headache, nausea, dizziness, vomiting, lethargy and feeling weakness. The chronic exposure of $\mathrm{CO}$ causes cardiovascular or neurobehavioral effects created and acute exposure cause coma and death problems created [45].

A catalytic converter is used in automobile vehicles for emission control device that converts the toxic pollutants emission from the internal combustion engines into less toxic pollutants by a catalytic oxidation reaction [6-7]. There are two diverse types of catalysts for CO 
oxidation at low temperatures have developed, the first one includes high surface area precious metal based catalysts and the second one incorporates the transition metal oxide-based catalysts $[8,9]$. The hopcalite catalyst in the form of $\mathrm{CuMnO}_{\mathrm{x}}$ is a well-known catalyst for low-temperature $\mathrm{CO}$ oxidation process and its application in many different fields like air purification devices, fuel cells, gas masks and automobile emissions control purposes [10]. A literature survey reveals that $\mathrm{CuMnO}_{\mathrm{x}}$ catalyst is highly active in the amorphous state even at room temperature, but it has observed that the $\mathrm{CuMnO}_{\mathrm{x}}$ catalyst lose their activity after exposition at temperatures above $500{ }^{\circ} \mathrm{C}$, where crystallization of the spinel $\mathrm{CuMn}_{2} \mathrm{O}_{4}$ was occurred [11,12].

The preparation method is affected by the structural properties of the catalysts, like particle size, shape, surface area, pore volume, pore size, phases and the strength of interaction, which in turn determined the redox property and reactivity of the final catalysts $[13,14]$. A lot of interest has been given to modification of the $\mathrm{CuMnO}_{\mathrm{x}}$ catalyst to remove its faults of moisture for deactivation and lower activity $[15,16]$. The optimization in $\mathrm{CuMnO}_{\mathrm{x}}$ catalyst during the preparation conditions like drying temperature, drying time, calcination temperature, calcination time and the molar ratio of Copper/Manganese (Cu:Mn) have improved the performance of $\mathrm{CuMnO}_{\mathrm{x}}$ catalysts for lowtemperature $\mathrm{CO}$ oxidation [17]. In this paper, we have investigated the effect of a broad range of preparation parameters to enable the optimal catalyst preparation procedure to be identified.

To date, there are various methods have applied to the preparation of $\mathrm{CuMnO}_{\mathrm{x}}$ catalysts; it's including sol-gel, ultrasonic aerosol pyrolysis, co-precipitation, supercritical antisolvent precipitation and the reduction methods [10, 18]. In the above methods, the co-precipitation method can produce the highly active sites of the $\mathrm{CuMnO}_{\mathrm{x}}$ catalyst $[19,20]$. A co-precipitation method is used for the preparation of $\mathrm{CuMnO}_{\mathrm{x}}$ catalyst with a full range (Cu:Mn) in a CuMnOx solution, and after the precipitation conditions, the $(\mathrm{Cu}: \mathrm{Mn})$ ratio of the final catalyst is very similar to the $\left(\mathrm{Cu}^{2+}: \mathrm{Mn}^{2+}\right)$ ratio in the starting solutions [10,21]. There are many things, which can be varied during the catalyst preparation by co-precipitation method and the subsequent calcination step for controlling the performance of catalyst for $\mathrm{CO}$ oxidation [22].

The particle size of $\mathrm{CuMnO}_{\mathrm{x}}$ catalyst also influences the activity of the resulting catalyst. With the decreasing of particle size, the surface area of the catalyst increases, and more $\mathrm{CO}$ is oxidized into $\mathrm{CO}_{2}$ [23]. The drying temperature, calcination temperature and calcination time have a distinct effect on the catalyst performance, and its structure is analysis by TGA and X-ray diffraction results [23,24]. The novel redox method has been allowed for room temperature preparation of amorphous $\mathrm{CuMnO}_{\mathrm{x}}$ catalyst with high surface areas and high catalytic activity for $\mathrm{CO}$ oxidation at ambient temperature [25]. The prepared $\mathrm{CuMnO}_{\mathrm{x}}$ catalyst in the flowing air calcination conditions (FAC) is characterization by several techniques like XRD, FTIR, BET, SEM-EDX and XPS. The structural, morphological and catalytic properties of $\mathrm{CuMnO}_{\mathrm{x}}$ catalyst is prepared by redox method in flowing air calcination (FAC) conditions as compare with the catalyst activity test results and their characterization work [26-28]. In this paper, we have studied the optimization preparation parameters of $\mathrm{CuMnO}_{\mathrm{x}}$ catalyst and their excellent performance for $\mathrm{CO}$ oxidation at a low temperature.

The main aim of this paper to understand the particular effects of a range of preparation variables are investigated in detail. The novelty of this paper to find out the optimum preparation parameters of $\mathrm{CuMnO}_{\mathrm{x}}$ catalyst to get the best activity results for $\mathrm{CO}$ oxidation at low temperature. Generally, the $\mathrm{CuMnO}_{\mathrm{x}}$ catalyst containing the copper and manganese mixed oxide phases are found to be the most active phases. The results are interpreted in terms of the structure of the active catalyst. The present research shows that $\mathrm{CuMnO}_{\mathrm{x}}$ catalyst preparation parameter is crucial importance in controlling the catalytic performance. We are now extending these previous studies to investigate the effect of a broad range of preparation parameters to enable the optimal catalyst preparation procedure to be identified. The unique finding in the precipitation and calcination conditions has a significant effect on the performance of $\mathrm{CuMnO}_{\mathrm{x}}$, catalysts for $\mathrm{CO}$ oxidation at low temperature. The optimum drying temperature, time, particle size, and $\mathrm{CO}$ flow rate is first time investigated in this paper.

\section{Experimental}

\subsection{Catalyst preparation}

The $\mathrm{CuMnO}_{\mathrm{x}}$ catalyst is prepared by the coprecipitation method and all the materials use for the preparation of catalyst they are AR grade. The aqueous solution manganese acetate $\left(\mathrm{Mn}\left(\mathrm{CH}_{3} \mathrm{COO}\right)_{2} .4 \mathrm{H}_{2} \mathrm{O}\right)$ and copper(II) nitrate $\left(\mathrm{Cu}\left(\mathrm{NO}_{3}\right)_{2} .2 .5 \mathrm{H}_{2} \mathrm{O}\right)$ are premixed by stir- 
ring and precipitate by the addition of aqueous $\mathrm{KMnO}_{4}$ solution [10]. After precipitation filtering, washing the $\mathrm{CuMnO}_{\mathrm{x}}$ precursors several times with hot deionizer water. In the drying conditions, the temperature is varying from $\left(25-140{ }^{\circ} \mathrm{C}\right)$ at constant time in an oven and calcine in flowing air, varying temperature (200$\left.400{ }^{\circ} \mathrm{C}\right)$. The amount of Copper is added varying to the preparation of $\mathrm{CuMnO}_{\mathrm{x}}$ catalysts with nominal (Cu:Mn) molar ratios. After drying the precursors, their granules are crushed into powdered form for activity measurement purposes [18].

\subsection{Characterization of catalysts}

The Scanning electron micrographs (SEM) produced the high-resolution image of the catalyst by an electron beam, and the image of the catalyst is recorded on Zeiss EVO 18 (SEM) instrument. The magnification images 5000X and the accelerating voltage $15 \mathrm{kV}$ is applied. It provides information about the average aggregate size, crystallinity degree and the microstructures of the catalyst. The X-ray diffraction (XRD) analysis of the catalyst is conceded out by using Rigaku D/MAX-2400 diffractometer with $\mathrm{Cu}-\mathrm{Ka}$ radiation at $40 \mathrm{kV}$ and $40 \mathrm{~mA}$. It is a rapid analytical technique primarily applied for the measurement of a crystal orientation, phase identification, crystallite size, unit cell dimensions and crystal defects, etc. The Fourier transforms infrared spectroscopy (FTIR) provides information about the kinds of material present in a catalyst sample surfaces by their peak values. The measurement is done by Shimadzu 8400 FTIR spectrometer in the range of $400-4000 \mathrm{~cm}^{-1}$.
The X-ray photoelectron spectroscopy (XPS) analysis provides information about the surface compositions and chemical states of the basic elements present in a catalyst. It is measured with Amicus spectrometer equipped with $\mathrm{Al} \mathrm{Ka} \mathrm{X}$-ray radiation at a voltage of $15 \mathrm{kV}$ and current of $12 \mathrm{~mA}$. The Brunauer-EmmettTeller analysis (BET) provides information about the specific surface area, pore volume and pore size of the catalyst. The isotherm is recorded by Micromeritics ASAP 2020 analyzer with the physical adsorption of $\mathrm{N}_{2}$ at the temperature of liquid nitrogen $\left(-196{ }^{\circ} \mathrm{C}\right)$ with an average pressure range of $0.05-0.30 \mathrm{P} / \mathrm{P}_{\mathrm{o}}$.

\subsection{Catalytic activity measurements}

The catalysts are tested for CO oxidation using a fixed-bed tabular flow reactor under the following reaction conditions: $100 \mathrm{mg}$ of the catalyst with feed gas consisting of a lean mixture of $(2.5 \mathrm{vol} . \% \mathrm{CO})$ in air maintained at a total flow rate of $60 \mathrm{~mL} / \mathrm{min}$. The air feed is made free from moisture and $\mathrm{CO}_{2}$ by passing though it $\mathrm{CaO}$ and $\mathrm{KOH}$ pellets drying towers. The reaction temperature is started from ambient to $140{ }^{\circ} \mathrm{C}$ at a heating rate of $1^{\circ} \mathrm{C} / \mathrm{min}$. The experimental apparatus setup for testing the catalyst in reaction system should be presented in below. The experimental apparatus setup for testing the $\mathrm{CuMnO}_{\mathrm{x}}$ catalyst for $\mathrm{CO}$ oxidation is shown in Figure 1.

The rate of heating is controlled with the assist of a microprocessor based temperature controller. The catalytic experiments are conceded under the steady state conditions. The flow rate of $\mathrm{CO}$ and air were monitored with the help of digital gas flow meters. The gaseous

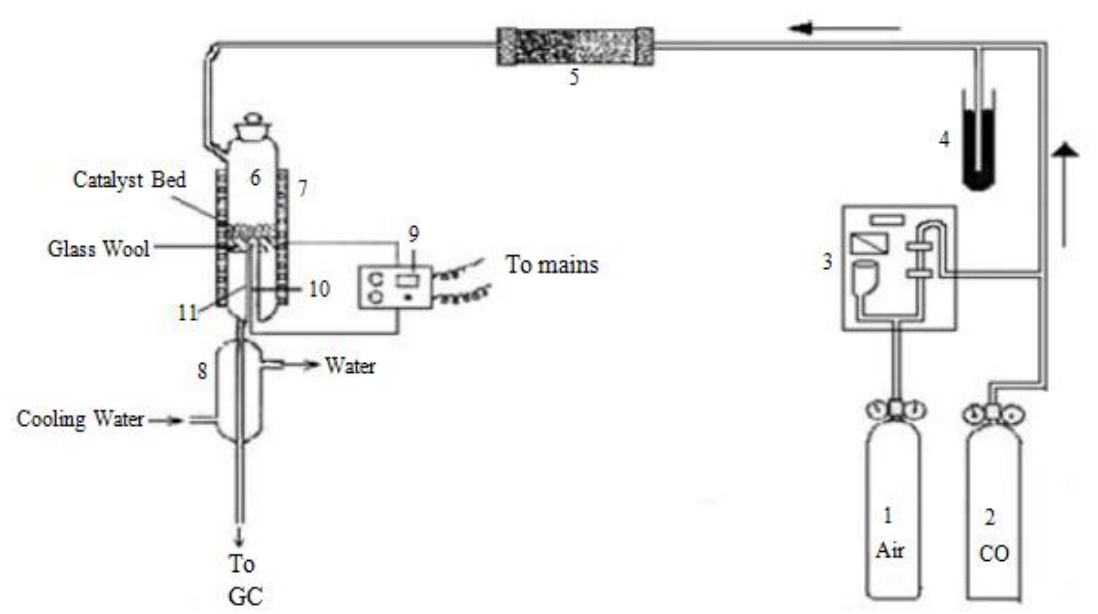

1. Air Cylinder, 2. CO Cylinder, 3. Digital Gas Flow Meter, 4. Hg Safety Device, 5. Moisture and $\mathrm{CO}_{2}$ trap, 6. Reactor, 7. Split-open Fumance, 8. Condenser, 9. Temperature Indicator Controller, 10. Thermocouple, 11. Thermocouple Well

Figure 1. Experimental apparatus setup for testing the catalyst 
products are analyzed by an on-line gas chromatograph (Nucon Series 5765) equipped with a methaniser, Porapak Q column, and FID detector.

\subsection{Mechanisms for $\mathrm{CO}$ oxidation reaction}

In the $\mathrm{CO}$ oxidation process, the oxygen is first adsorbed on $\mathrm{CuMnO}_{\mathrm{x}}$ surface with the energy of activation. When the temperature is reached at adequate level, so the adsorption of oxygen reaches enough proportions, therefore any $\mathrm{CO}$ pass over the catalyst surfaces either reacts directly with the adsorbed oxygen or else first adsorbed and then reacts, after which the $\mathrm{CO}$ is converted. The catalytic air oxidation of $\mathrm{CO}$ to $\mathrm{CO}_{2}$ is the promising way to control the $\mathrm{CO}$ emission (Equation 1).

$$
\mathrm{CO}+1 / 2 \mathrm{O}_{2} \rightarrow \mathrm{CO}_{2}
$$

The distinct reaction mechanisms are consistent with the observed kinetics. The first mechanism represents the broadly accepted $\mathrm{CO}$ oxidation reaction on a $\mathrm{CuMnO}_{\mathrm{x}}$ catalyst surface that involves $\mathrm{O}_{2}$ adsorption to form $\mathrm{O}_{2}{ }^{*}$ precursors, which separate on a vicinal vacancy. In the second mechanism, $\mathrm{O}_{2}$ activation occurs via the kinetically applicable $\mathrm{CO}^{*}$ assisted $\mathrm{O}_{2}$ dissociation step without the specific involvement of stable $\mathrm{O}_{2}{ }^{*}$ precursors. The Co-precipitation method is allowed for the synthesis of amorphous catalysts with high surface areas and high catalytic performance.

\section{Results and Discussion}

The characterization of $\mathrm{CuMnO}_{\mathrm{x}}$ catalyst sample prepared in flowing air calcination (FAC) conditions was done by the different techniques and the activities of the catalyst for $\mathrm{CO}$ oxidation were discussed below.

\subsection{Catalyst characterization}

The characterization of the optimized $\mathrm{CuMnO}_{\mathrm{x}}$ catalyst prepared in flowing air calcination condition was provided information about the surface area, morphology, composition, binding energy, pore volume, pore size, chemical state and the percentage of different materials presence in a catalyst surface.

\subsubsection{Morphology of the catalysts}

The Scanning Electron Micrographs (SEM) instrument was used for the microstructure analysis of the optimized $\mathrm{CuMnO}_{\mathrm{x}}$ catalyst prepare in flowing air calcination (FAC) conditions. The $\mathrm{CuMnO}_{\mathrm{x}}$ catalyst was composed of different aggregates size of nanoparticles as shown in Figure 2.

In Figure 2, SEM micrographs the presence of the particles in a $\mathrm{CuMnO}_{\mathrm{x}}$ catalyst comprising coarse and excellent sizes in nature. The particles are normally least agglomerated, highly porous, high surface area and uniformly distributed. It is observed that the size of particles presence in a catalyst surfaces decreases by increasing the $\mathrm{Mn}$ contents in $\mathrm{CuMnO}_{\mathrm{x}}$ catalyst [29]. The presence of $\mathrm{Mn}$ phase has shown to stabilize smaller $\mathrm{Cu}$ metal crystallites. The particles presence in a catalyst surfaces is uniformly distributed over the all surface area of the catalyst. Due to the smaller particle size of catalyst, more and more CO dispersed on the surface of the catalyst. Therefore, the activity of the catalyst is increased $[29,30]$. The surface rebuilding behavior of different size of particles presence in a catalyst surfaces during the period of prolonged exposure to $\mathrm{CO}$ gas. The drying of the precursor at $110{ }^{\circ} \mathrm{C}$ and calcination it $300{ }^{\circ} \mathrm{C}$ formation of a $\mathrm{Cu}_{1.2} \mathrm{Mn}_{1.8} \mathrm{O}_{4}$, and the high-temperature calcination oxidized all the impurities presence in a catalyst surfaces.
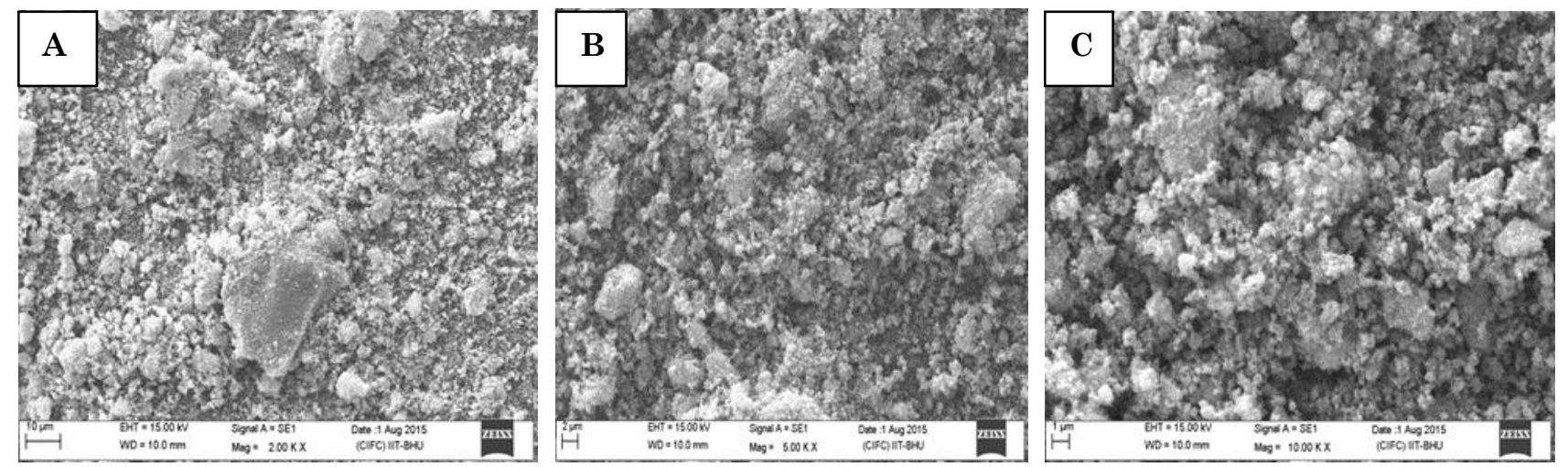

Figure 2. SEM image of $\mathrm{CuMnO}_{\mathrm{x}}$ catalyst prepared in FAC conditions at different magnification, A) 2.0KX, B) 5.0KX, and C) $10.0 \mathrm{KX}$ 


\subsubsection{Elemental analysis}

In the $\mathrm{CuMnO}_{\mathrm{x}}$ catalyst, the percentages of different elements are present analysis by the Scanning Electron Microscopy (SEM) with Energy Dispersive X-Ray analysis (SEM-EDX) techniques. It is evident from the results of SEM-EDX analysis shown in Figure 3 that the $\mathrm{CuMnO}_{\mathrm{x}}$ catalyst is pure there will be not presence any types of impurities in a catalyst surfaces [19]. It is apparent from the table and figures that the atomic percentage of $\mathrm{Mn}$ is higher in comparison of $\mathrm{Cu}, \mathrm{O}$, and the weight proportion of $\mathrm{Mn}$ is also a greater in comparison of $\mathrm{Cu}$ and $\mathrm{O}[31]$.

The element, weight (\%), atomic (\%) of CuMnOx catalyst are shown in Table 1 [18]. The atomic percentage of $\mathrm{Cu}, \mathrm{Mn}$, and $\mathrm{O}$ in the $\mathrm{CuMnO}_{\mathrm{x}}$ catalyst resulted by flowing air calcination condition is $14.47 \%, 54.41 \%$, and 31.12 $\%$ respectively. The weight proportion of $\mathrm{Cu}$, $\mathrm{Mn}$, and $\mathrm{O}$ in this $\mathrm{CuMnO}_{\mathrm{x}}$ catalyst is $16.61 \%$, $56.38 \%$, and $27.01 \%$ respectively. The atomic ratio of $(\mathrm{Cu}: \mathrm{Mn})$ in the $\mathrm{CuMnO}_{\mathrm{x}}$ catalyst is approximate, 0.294 , and the weight ratio of (Cu:Mn) in the $\mathrm{CuMnO}_{\mathrm{x}}$ catalyst is around 0.265 . It can be seen that $\mathrm{CuMnO}_{\mathrm{x}}$ catalyst has similar morphologies which composed of irregular size and shape particles. The reduction in crystallite size presence of the particles in
$\mathrm{CuMnO}_{\mathrm{x}}$ catalyst can be attributed to the $\mathrm{MnO}_{2}$ acting as a simple spacer between $\mathrm{Cu}$ crystallites and subsequently preventing sintering during the heat treatment [26].

The presence of lattice oxygen mobility species in the $\mathrm{CuMnO}_{\mathrm{x}}$ catalyst has enhanced the reaction rate and it might provide the more surface area of active oxygen species for CO oxidation reaction [10]. The morphologies are indicating that the types of precipitants and precursors have an influence on the catalyst performances. The abundant surface oxygen atoms presence on the catalyst surfaces can react with the absorbed $\mathrm{CO}$ and thus lead to a better catalytic activity in the Mars-van Krevelen type mechanism [32]. With the increasing Mn contents in $\mathrm{CuMnO}_{\mathrm{x}}$ catalyst, the pore size distributions become wider; therefore, moremore $\mathrm{CO}$ oxidized into $\mathrm{CO}_{2}$ [18]. The weight ratio percentage of $(\mathrm{Cu}: \mathrm{Mn})$ in the $\mathrm{CuMnO}_{\mathrm{x}}$ catalyst is similar to the ratio values use in the synthesis solutions.

\subsubsection{Phase identification and cell dimensions}

X-ray Diffraction (XRD) studies of the $\mathrm{CuMnO}_{\mathrm{x}}$ catalyst are carried out to identify the phases and oxidation states present in the sample. The XRD pattern of the $\mathrm{CuMnO}_{\mathrm{x}}$ catalyst produced by flowing air calcination (FAC)
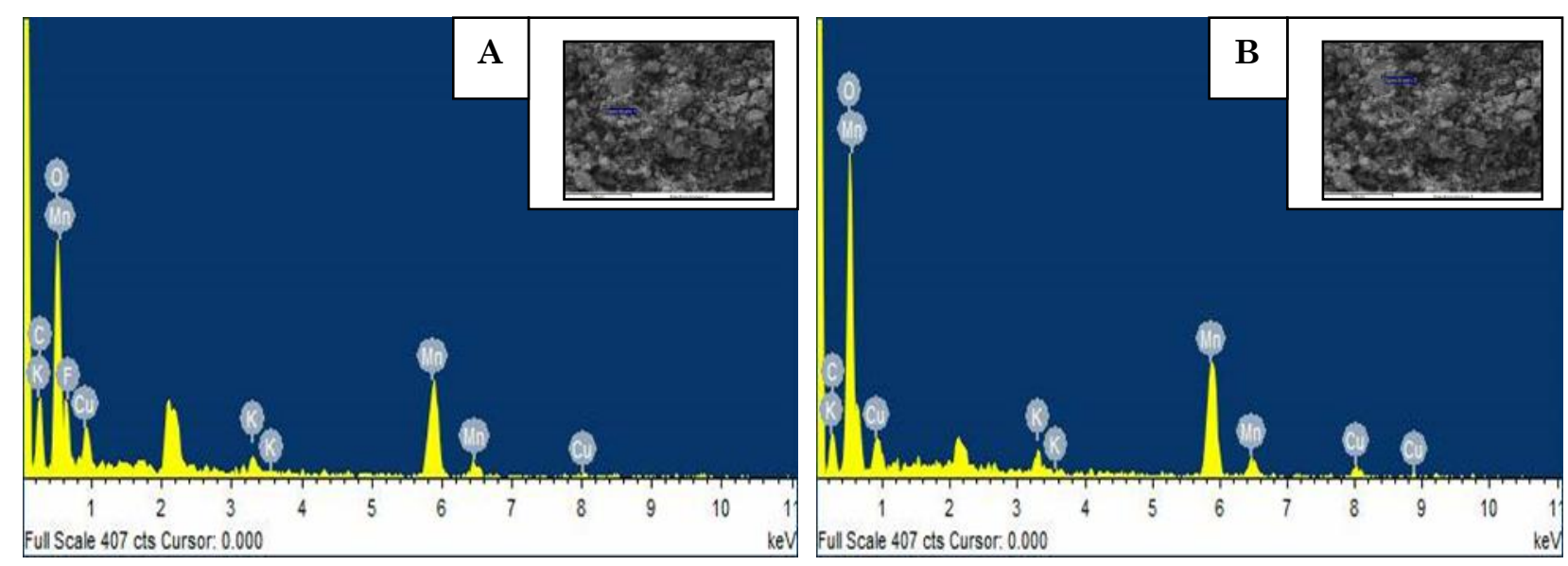

Figure 3. The SEM-EDX image of $\mathrm{CuMnO}_{\mathrm{x}}$ catalyst prepared in FAC conditions at different magnification A) $2.0 \mathrm{KX}$ and B) $5.0 \mathrm{KX}$

Table 1. The atomic and weight percentage of $\mathrm{CuMnO}_{\mathrm{x}}$ catalyst

\begin{tabular}{ccc}
\hline Elemental & Weight $(\%)$ & Atomic (\%) \\
\hline $\mathrm{O}$ & 31.12 & 27.01 \\
$\mathrm{Mn}$ & 54.41 & 56.38 \\
$\mathrm{Cu}$ & 14.47 & 16.61 \\
Total & 100 & 100 \\
\hline
\end{tabular}


conditions is displayed in Figure 4.

The diffraction peak at $2 \theta$ is 37.20 corresponds to lattice plane (2 21 ) of face-centered cubic $\mathrm{Cu}_{1.2} \mathrm{Mn}_{1.8} \mathrm{O}_{4}$ (PDF-71-1144 JCPDS file). The crystallite size of the catalyst is $2.823 \mathrm{~nm}$. The smaller size particles presence in a $\mathrm{CuMnO}_{\mathrm{x}}$ catalyst surfaces, therefore it is more active for $\mathrm{CO}$ oxidation at a low temperature. The calcination temperature $300^{\circ} \mathrm{C}$ is found an optimum calcination temperature because raising the temperature beyond $300{ }^{\circ} \mathrm{C}$ a loss of crystalline has occurred and after some time the material is obtained almost entirely amorphous in nature [17,33]. The interaction of $\mathrm{CuO}$ and $\mathrm{MnO}_{\mathrm{x}}$, with the formation of a highly disorder mixed oxide, is the cause of higher catalytic activity for $\mathrm{CO}$ oxidation.

3.1.4 Identification of the materials presents in a catalyst

The identification of the metal-oxygen bonds present in the $\mathrm{CuMnO}_{\mathrm{x}}$ catalyst surfaces is made by Fourier transform infrared spectroscopy (FTIR) analysis. The different peaks are shows various types of chemical groups present on the catalyst surfaces. The FTIR transmission spectra of $\mathrm{CuMnO}_{\mathrm{x}}$ catalyst prepared in flowing air calcination (FAC) condition is shown in Figure 5.

There are five peaks we obtained in the preparation of $\mathrm{CuMnO}_{\mathrm{x}}$ catalyst in flowing air calcination (FAC) conditions. The main stretching bond of $\mathrm{Mn}-\mathrm{O}, \mathrm{CuO}, \mathrm{CO}_{3}{ }^{2-}$ and $\mathrm{C}=\mathrm{O}$ group is present in this catalyst surfaces. The transmission spectra at $1630 \mathrm{~cm}^{-1}$ are assigned to a $\mathrm{MnO}_{2}$ group, $1290 \mathrm{~cm}^{-1}$ show $\mathrm{CO}_{3}{ }^{2-}$ group, and $540 \mathrm{~cm}^{-1}$ shows $\mathrm{CuO}$ group presence in a catalyst surfaces. The other phases like $\mathrm{C}=\mathrm{O}$ and hydroxyl group are present at $2350 \mathrm{~cm}^{-1}$ and $3480 \mathrm{~cm}^{-1}$, respectively. In the flowing air, calci-

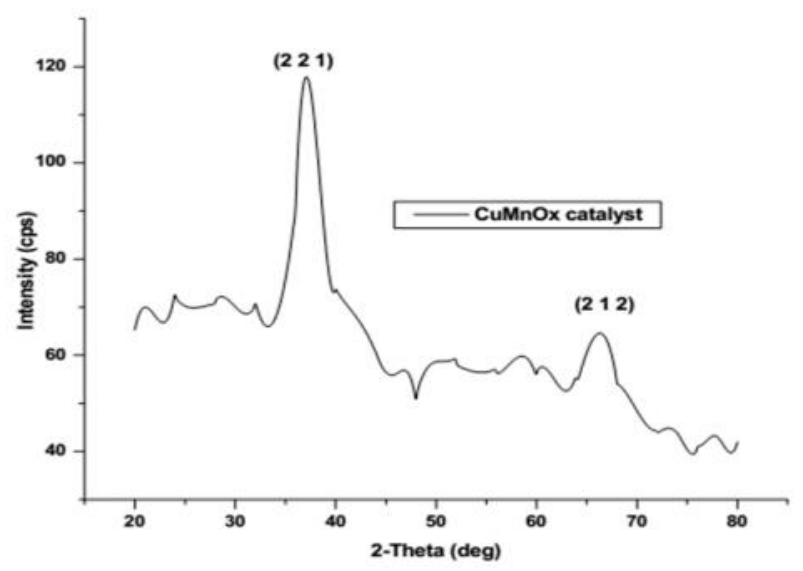

Figure 4. XRD analysis of $\mathrm{CuMnO}_{\mathrm{x}}$ catalyst prepared in FAC conditions nation prepared $\mathrm{CuMnO}_{\mathrm{x}}$ catalyst; this originates from the stretching vibrations of the metal-oxygen bond and confirms the presence of $\mathrm{CuO}$ and $\mathrm{MnO}_{2}$ phases. The weak band at $1290 \mathrm{~cm}^{-1}$ indicates the presence of some carbonaceous group in the $\mathrm{CuMnO}_{\mathrm{x}}$ sample. The $\mathrm{MnO}_{\mathrm{x}}$ deposits in a $\mathrm{CuMnO}_{\mathrm{x}}$ catalyst are intimate contact with $\mathrm{CuO}$ crystallites and favoring oxygen transfer between the two metal oxides. This type of $\mathrm{CuO}-\mathrm{MnO}_{2}$ structure interaction led to a formation of the $\mathrm{Mn}_{3} \mathrm{O}_{4}$ phase. The important thing that controls in the propagation of this $\mathrm{CO}$ oxidation reaction is the thermal diffusion of $\mathrm{Cu}$ and $\mathrm{Mn}$ cations.

\subsubsection{Identification and quantification of ele- ments}

The oxidation state and binding energy of $\mathrm{CuMnO}_{\mathrm{x}}$ oxide are investigated by the X-ray photoelectron spectroscopy (XPS) analysis. It can be proposed that the higher binding energy is preferably for the oxidation reaction. In the below Figure 6 display the XPS spectra of $\mathrm{CuMnO}_{\mathrm{x}}$ catalyst prepared in flowing air calcination conditions. The binding energy of $\mathrm{Mn}_{2} \mathrm{p}_{3 / 2}, \mathrm{Cu} 2 \mathrm{p}_{3 / 2}$ and $\mathrm{O}(1 \mathrm{~s})$ are $641.8 \mathrm{eV}, 936.5$ $\mathrm{eV}$, and $530.8 \mathrm{eV}$, respectively, and the chemical state of $\mathrm{C}, \mathrm{Cu}, \mathrm{Mn}$, and $\mathrm{O}$ are $\mathrm{C}-\mathrm{O}-\mathrm{C}$, $\mathrm{Cu}(\mathrm{II})$ oxide, $\mathrm{MnO}_{2}$ and organic $\mathrm{C}-\mathrm{O}$ form, respectively.

Generally, there are two different types of oxygen present in the $\mathrm{CuMnO}_{\mathrm{x}}$ catalysts with the binding energy of (529.2-530 eV) and (531.3-532.2 eV). The chemisorbed oxygen recognized as (denoted as $\mathrm{Oa}$, such as: $\mathrm{O}_{2}{ }^{2-}$, $\mathrm{O}$, $\mathrm{OH}, \mathrm{CO}_{3}{ }^{2-}$, etc.), and lattice oxygen (denoted as $\mathrm{O}_{1}$ such as $\mathrm{O}^{2-}$ ). In our present study oxygen with the binding energy of $530.8 \mathrm{eV}$ is the primary form and could be assigned to chemisorbed oxygen (Oa). The presence of lattice oxy-

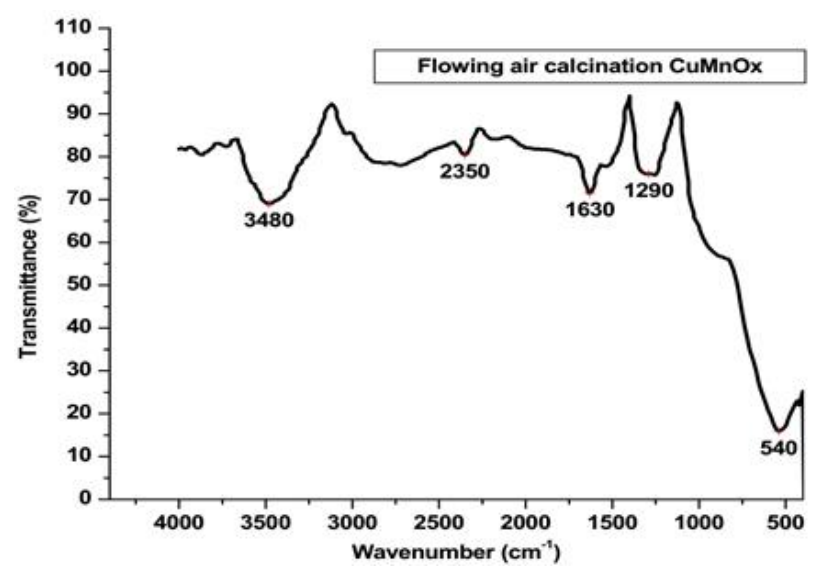

Figure 5. FTIR analysis of $\mathrm{CuMnO}_{\mathrm{x}}$ catalyst prepared in FAC conditions 
gen is very low in flowing air calcination prepare $\mathrm{CuMnO}_{\mathrm{x}}$ catalyst. It is a well known that high concentration of surface chemisorbed oxygen (as the most active oxygen) is preferable for enhancing the catalytic activity of $\mathrm{CO}$ oxidation reactions [34]. It is found that $\mathrm{Mn}\left(\mathrm{CH}_{3} \mathrm{COO}\right)_{2} .4 \mathrm{H}_{2} \mathrm{O}$ usually decomposed into $\mathrm{MnO}_{2}$ and $\mathrm{Cu}\left(\mathrm{NO}_{3}\right)_{2} .3 \mathrm{H}_{2} \mathrm{O}$ usually decomposed into $\mathrm{Cu}$ (II) oxide form into the flowing air calcination conditions. In Table 2, we have mentioned that the chemical state and binding of $\mathrm{CuMnO}_{\mathrm{x}}$ catalyst prepared in flowing air calcination conditions.

These binding energies recommend that the oxide $\left(\mathrm{O}^{2-}\right)$ species are mostly near the surface of $\mathrm{CuMnO}_{\mathrm{x}}$ catalyst and it is usually accepted that $\mathrm{Cu}$ exists in the (II) oxidation state in binary form. The table and figure indicate that at least some of the $\mathrm{Cu}^{2+}$ and $\mathrm{Mn}^{2+}$ phase exist near the surface of catalysts. The opportunity of having surface $\mathrm{Mn}$ atoms in oxidation states more than $3^{+}$, as simply by the corresponding electron binding energy values and the $\mathrm{O} / \mathrm{Mn}$ atomic ratio.

\subsubsection{Surface area measurement of catalyst}

The surface area of $\mathrm{CuMnO}_{\mathrm{x}}$ catalyst is analysis by Brunauer-Emmett-Teller analysis
(BET) technique. The surface area, pore volume and pore size of $\mathrm{CuMnO}_{\mathrm{x}}$ catalyst prepare in flowing air calcination conditions are discuss in Table 3 [34-35]. Clearly, the textural property of $\mathrm{CuMnO}_{\mathrm{x}}$ catalyst is superior to active for $\mathrm{CO}$ conversion at low temperature. The average pore volume and pore size of $\mathrm{CuMnO}_{\mathrm{x}}$ catalyst are $0.460 \mathrm{~cm}^{3} / \mathrm{g}$ and $52.30 \AA$, respectively. The larger number of more pores presence on a catalyst surface, it means highly interaction of $\mathrm{CO}$ molecules with catalyst surfaces, and it has shown the better catalytic activity [26].

The further calcination of $\mathrm{CuMnO}_{\mathrm{x}}$ precursor led to significantly decreasing the surface area of resulting catalyst. A correlation between the increasing of $\mathrm{Mn}$ concentration and the steady state $\mathrm{CuMnO}_{\mathrm{x}}$ catalyst activity is increased at certain levels is revealed [18]. From the characterization work, we can get that the phase composition and reduction properties of $\mathrm{CuMnO}_{\mathrm{x}}$ catalyst are highly depended on the (Cu:Mn) molar ratio [12].

\subsection{Activity test of $\mathrm{CuMnO}_{\mathrm{x}}$ catalyst}

In the activity test, we have analyzed the effectiveness of resulting $\mathrm{CuMnO}_{\mathrm{x}}$ catalyst pre-
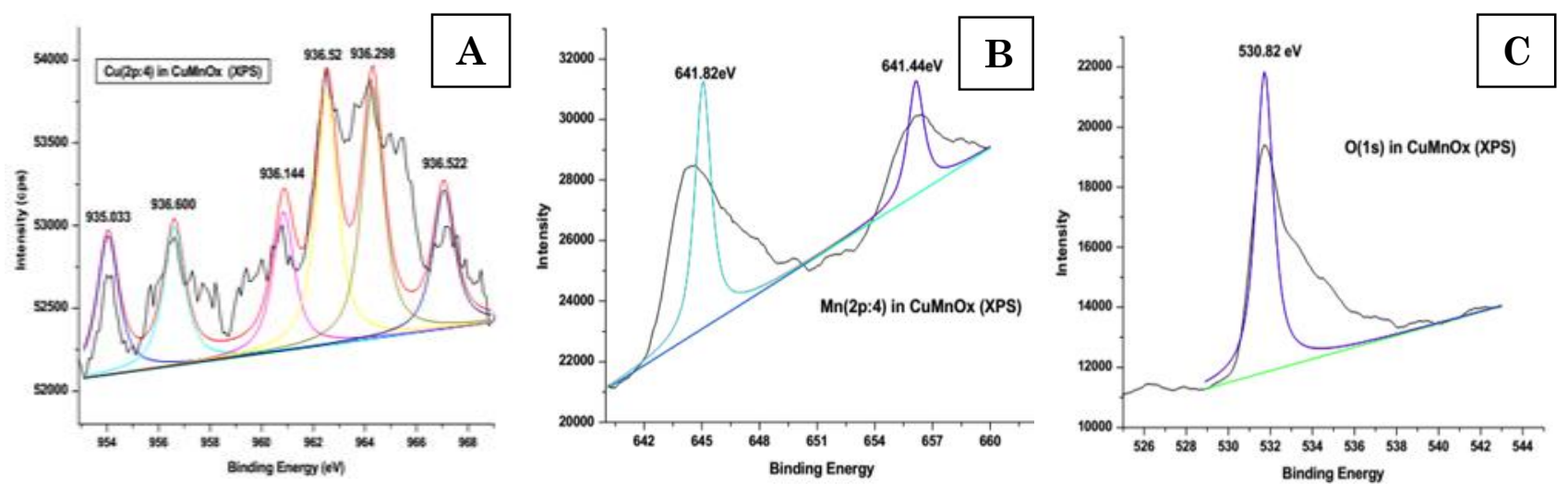

Figure 6. XPS analysis of A) $\mathrm{Cu}$ element, B) Mn element, and C) O element in a $\mathrm{CuMnO}_{\mathrm{x}}$ catalyst

Table 2. Chemical state and binding energy of $\mathrm{CuMnO}_{\mathrm{x}}$ catalysts

\begin{tabular}{ccccc}
\hline \multirow{2}{*}{ Sample } & \multicolumn{5}{c}{ Elements } \\
\cline { 2 - 5 } & $\mathrm{C}$ & $\mathrm{Cu}$ & $\mathrm{Mn}$ & $\mathrm{O}$ \\
\hline \multirow{2}{*}{$\mathrm{CuMnO}_{\mathrm{x}}(\mathrm{FAC})$} & \multirow{2}{*}{$\mathrm{C}-\mathrm{O}-\mathrm{C}$} & $\mathrm{Cu}$ (II) Oxide & $\mathrm{MnO}_{2}$ & Organic C-O \\
& & $936.5 \mathrm{eV}$ & $641.8 \mathrm{eV}$ & $530.8 \mathrm{eV}$ \\
\hline
\end{tabular}

Table 3. The surface area, pore volume and pore size of $\mathrm{CuMnO}_{\mathrm{x}}$ catalyst

\begin{tabular}{cccc}
\hline Catalyst Name & Surface Area $\left(\mathrm{m}^{2} / \mathrm{g}\right)$ & Pore Volume $\left(\mathrm{cm}^{3} / \mathrm{g}\right)$ & Pore Size $(\AA)$ \\
\hline $\mathrm{CuMnO}_{\mathrm{x}}(\mathrm{FAC})$ & 210.50 & 0.460 & 52.30 \\
\hline
\end{tabular}


pared in different conditions for $\mathrm{CO}$ oxidation purposes.

\subsubsection{Effects of (Cu:Mn) molar ratio}

The $\mathrm{CuMnO}_{\mathrm{x}}$ catalyst has a high potential due to their high thermal stability, chemical resistance, and lower moisture poisoning. This catalyst is more efficient in comparison to $\mathrm{Cu}$ and Mn pure oxides. In this paper, we have studied the different molar ratio of copper and manganese $(\mathrm{Cu}: \mathrm{Mn})$ in a $\mathrm{CuMnO}_{\mathrm{x}}$ catalyst on the catalytic activity for $\mathrm{CO}$ oxidation. The amount of $\mathrm{Cu}$ is added vary with the preparation of $\mathrm{CuMnO}_{\mathrm{x}}$ catalysts with nominal (Cu:Mn) molar ratios of 1/2, 1/4, 1/6, 1/8, 1/10, and 1/12 [10]. In Figure 7, we have found that there is two type of graphs, in the first graph the molar ratio of $\mathrm{Mn}$ is made constant, and the molar ratio of $\mathrm{Cu}$ is varied and in the second graph the molar ratio of $\mathrm{Cu}$ is made constant, and the molar ratio of $\mathrm{Mn}$ is varied. The amazing thing we have found out that the increasing $\mathrm{Cu}$ concentration more than $13 \%$ in $\mathrm{Cu}-\mathrm{Mn}$ catalysts has a depressing effect on the catalytic performance.

The activity of the catalyst increases with the increasing $\mathrm{Mn}$ concentration in the $\mathrm{CuMnO}_{\mathrm{x}}$ catalyst sample and the optimum molar ratio of $(\mathrm{Cu}: \mathrm{Mn})$ in the $\mathrm{CuMnO}_{\mathrm{x}}$ catalyst is (1:8) in the flowing air calcination conditions. The further increasing of Mn percentage in the $\mathrm{CuMnO}_{\mathrm{x}}$ catalyst the activity decreases. The CO oxidation efficiency was confirmed as a function of the $(\mathrm{Cu}: \mathrm{Mn})$ ratio and the reaction time. The binary $\mathrm{Cu}-\mathrm{Mn}$ oxides have a flexible metal valences $\left(\mathrm{Cu}^{1+/ 2+}\right.$ and $\left.\mathrm{Mn}^{3+/ 4+}\right)$ which give increase to their specific properties and excellent catalytic activity for CO oxidation [19]. The enhance catalytic performance can be explained by the improved lattice oxygen mobility, specific surface area, and pore volume into the $\mathrm{CuMnO}_{\mathrm{x}}$ catalysts. The binary $\mathrm{CuMnO}_{\mathrm{x}}$ mixed metal oxide has an excellent potential for practical applications to decrease $\mathrm{CO}$ in the atmosphere.

\subsubsection{Effects of particle size}

The size of particles presence in a catalyst surfaces is profoundly influenced by the reaction rate when the size of the particle is decreased; therefore their surface areas are increased and the ratio of catalyst surface area and reactant volume is playing a crucial role in controlling the reaction kinetics [32]. The reaction took place on the surface of the catalyst; therefore, increasing the surface area should raise the rate of reaction as well. The size and shape of the particles are a transaction between the lower pore diffusion effects. The particle size provides information about the responsive behavior of the catalysts in an individual process, and the effect of particle size might be attributed to the morphological changes [7].

In Figure 8, we have found that by reducing particle size, the activity of the catalyst increases. The sieve analysis is separate the different size of particle presence in a $\mathrm{CuMnO}_{\mathrm{x}}$ catalyst and the 60-micron $(\mu)$ particle size of $\mathrm{CuMnO}_{\mathrm{x}}$ catalyst is the optimum size of the
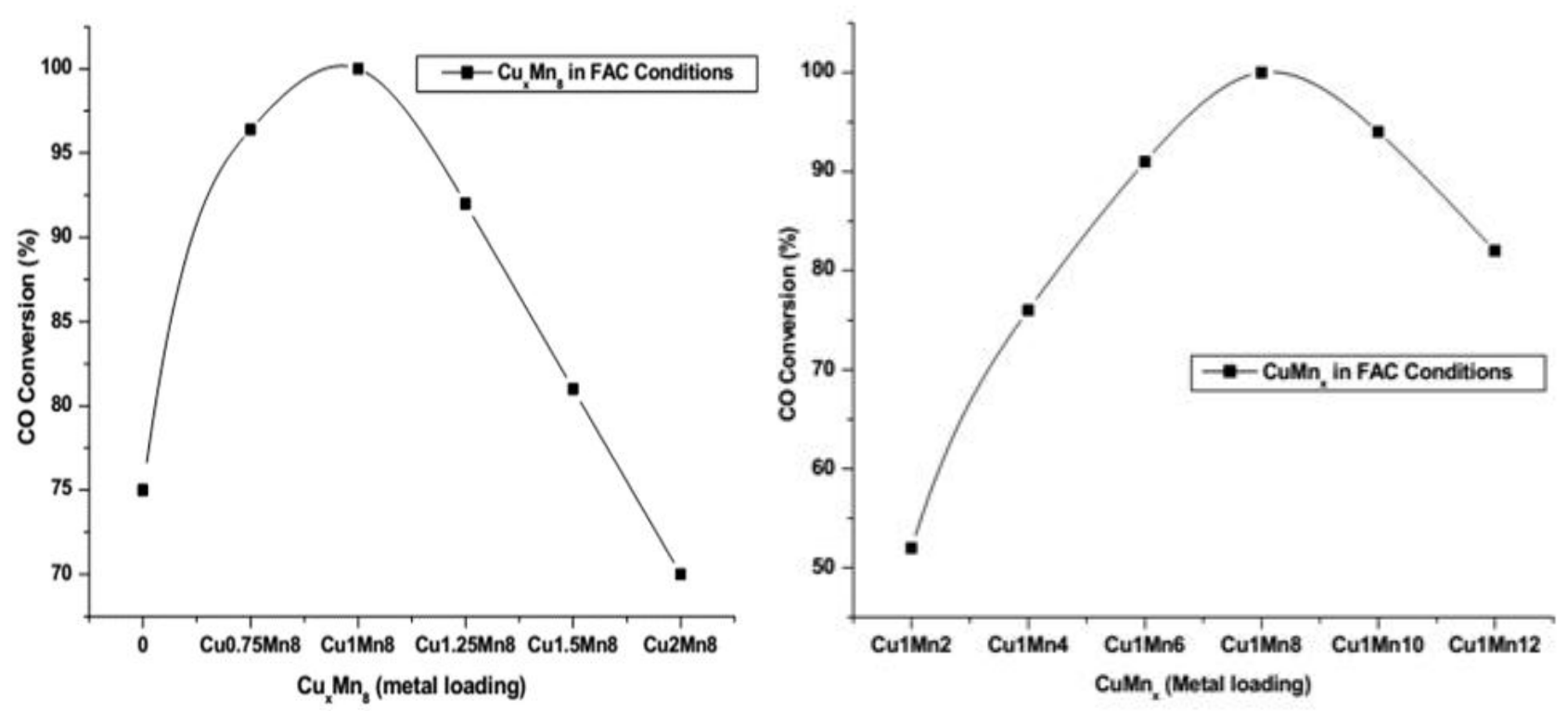

Figure 7. The molar ratio of $(\mathrm{Cu}: \mathrm{Mn})$ in $\mathrm{CuMnO}_{\mathrm{x}}$ catalyst, $\left.\mathrm{A}\right)$ the $\mathrm{Cu}$ is varied, and $\mathrm{Mn}$ is made constant, $\mathrm{B}$ ) the $\mathrm{Mn}$ is varied, and $\mathrm{Cu}$ is made constant 
catalyst for $\mathrm{CO}$ oxidation at a low temperature. When the size of particles presence in a catalyst surfaces is smaller than 10 nanometers, it containing about 10,000 atoms of catalyst and the movements of electrons in the metal are confined, so their internal energies are increases. The size, shape, and morphology of the $\mathrm{CuMnO}_{\mathrm{x}}$ catalyst particles are confirmed by the SEM, XRD, and BET characterization [36].

\subsubsection{Effects of drying temperature}

The activity of catalysts is carrying out to compare the efficiency produced by drying the precursor at different temperatures $\left(22-120{ }^{\circ} \mathrm{C}\right)$ for $12 \mathrm{~h}$ in flowing air calcination for $\mathrm{CO}$ oxidation. It can be seen from the Figure 9, that the activity of resulting catalyst increases with the increasing drying temperature of the precursor up to $110^{\circ} \mathrm{C}$, and further increasing the drying temperature, the activity decreases. Thus, the optimum drying temperature of the precursor is $110{ }^{\circ} \mathrm{C}$, which produced the catalyst exhibiting the highest activity for $100 \%$ CO conversion at $120{ }^{\circ} \mathrm{C}$. The temperature at which precipitation is carrying out does not significantly affect the bulk $(\mathrm{Cu}: \mathrm{Mn})$ ratio of the precipitate [37].

The activity of the final catalyst increases with the increasing of the precipitate drying temperature and from the activity test we have got the optimum drying temperature, of $\mathrm{CuMnO}_{\mathrm{x}}$ catalyst. In this case, $110{ }^{\circ} \mathrm{C}$ is considered to be a possible maximum operating temperature of the $\mathrm{CuMnO}_{\mathrm{x}}$ catalyst for $\mathrm{CO}$ oxidation. The activity of the catalyst for $\mathrm{CO}$ oxidation is influenced by the surface area, crystallinity and the presence of $\mathrm{Cu}^{2+}$ and $\mathrm{Mn}^{3+}$ ions on the surface of catalyst [25].

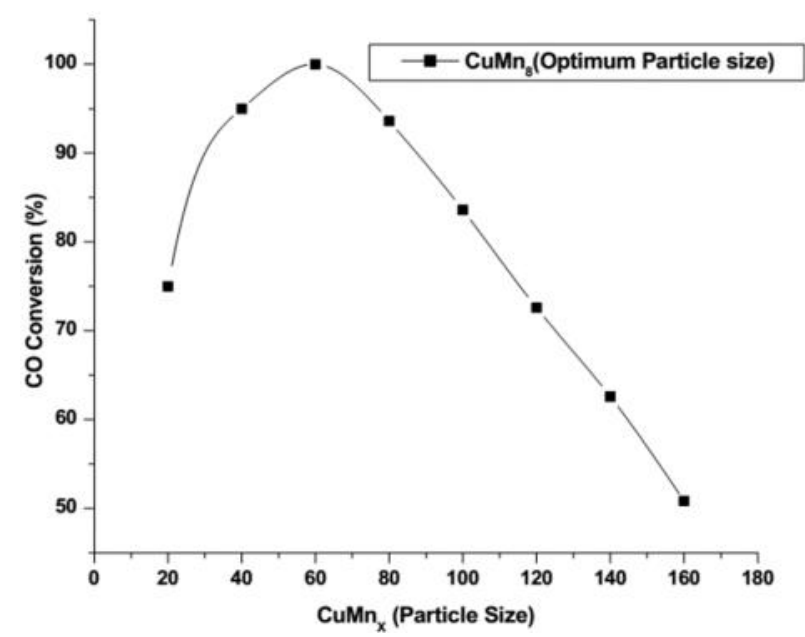

Figure 8. The optimization in the particle size of $\mathrm{CuMnO}_{\mathrm{x}}\left(\mathrm{CuMn}_{8}\right)$ catalyst

\subsubsection{Effects of drying time}

The drying steps showed a strong influence on the preparation of the final catalyst. The catalytic activity for the oxidation of $\mathrm{CO}$ is investigated in the range of materials and the activity with respect to time online. The drying times of $\mathrm{CuMnO}_{\mathrm{x}}$ precursor is intense influences the performance of resulting catalyst. The drying time highly effects on the catalyst activity as shown in Figure 10. The catalytic activity increases with the increasing of drying time up to $12 \mathrm{~h}$ of the precursor at a fixed temperature of $110{ }^{\circ} \mathrm{C}$. Therefore, at the temperature with further increasing the drying time the activity of the catalyst decreases. This result shows that drying the precipitate under these conditions for $12 \mathrm{~h}$ gives the highest $\mathrm{CO}$ conversion. During the drying period, the solution may be retained by the porous support, and it may be migrated by capillary flow and diffusion, therefore; the solute redistributed by desorption and re-adsorption [12]. When the solvent evaporates, precipitation of solute happens as the solution becomes supersaturated and brings crystallization of the precursors in the pores and an outer surface of the carrier.

The solvent is removing during the drying process, and the concentration of precursor will raise therefore the critical super saturation, precipitation will take place. The weakly interacting species can transfer over macroscopic distances during the drying step. The potential of drying is the effect on the volumetric heating of the material, removing the need for heat transport from the outer edge of the particle toward the center. The uniform drying reduces the convection so that more similar distributions are obtained in a catalyst. When the dry-

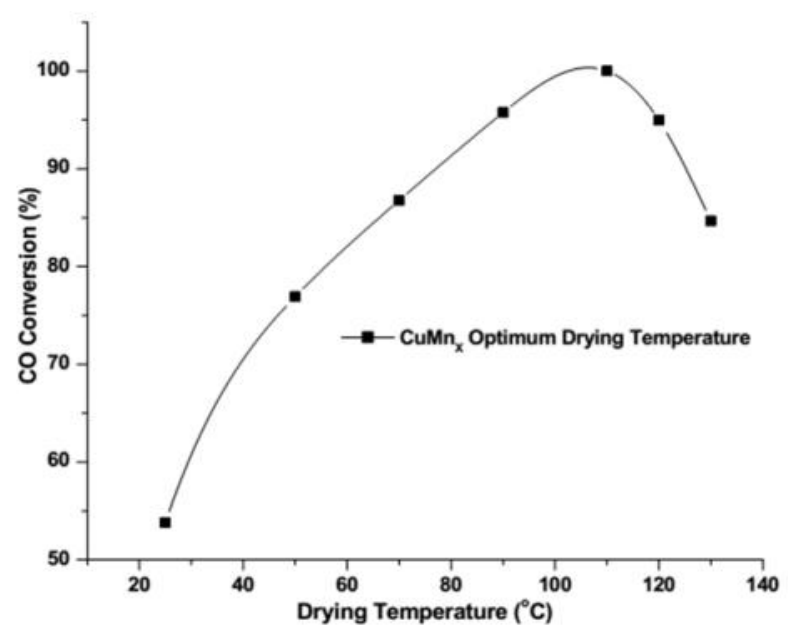

Figure 9. The optimization in the drying temperature of $\mathrm{CuMnO}_{\mathrm{x}}\left(\mathrm{CuMn}_{8}\right)$ catalyst 
ing is performing at rapid enough rates, it causes the gel to fragment into granules having the desired mean particle size.

\subsubsection{Effects of calcination temperature}

The calcination temperature of the precursor is highly affected on the performance of resulting catalyst so that it is necessary to find out the optimum calcination temperature of the catalyst. The calcination temperature of the catalyst is followed between the $\left(200-400{ }^{\circ} \mathrm{C}\right)$ in a flowing air calcination conditions. The percentage of $\mathrm{CO}$ oxidation is shown in Figure 11. With the increasing calcination temperature of the precursor, the catalytic activity is increasing, and it could be observed before reached to $300{ }^{\circ} \mathrm{C}$ temperature [15].

The optimum calcination temperature of $\mathrm{CuMnO}_{\mathrm{x}}$ catalyst is $300{ }^{\circ} \mathrm{C}$ and further increasing calcination temperature the activity is decreased. There was a correlation between the surface area and the calcination temperature of the catalyst [38]. When the calcination temperature of $\mathrm{CuMnO}_{\mathrm{x}}$ precursor was increased above $300{ }^{\circ} \mathrm{C}$, the exterior area decreased and analyzed by BET measurement. The crystallinity is also increased as the increasing calcination temperature of the precursor; therefore the diffraction peaks at the XRD analysis is more crystalline phases produce by calcination at 200-400 ${ }^{\circ} \mathrm{C}$ of temperature. The catalyst calcined at $300{ }^{\circ} \mathrm{C}$ for $2 \mathrm{~h}$ showed the best catalytic activity for complete oxidation of $\mathrm{CO}$ at $120{ }^{\circ} \mathrm{C}$ temperature. The increasing calcination temperature raises the oxidation of excess $\mathrm{Cu}^{2+}$ ions and decreases the concentration of surface oxygen vacancies; as a result the forma-

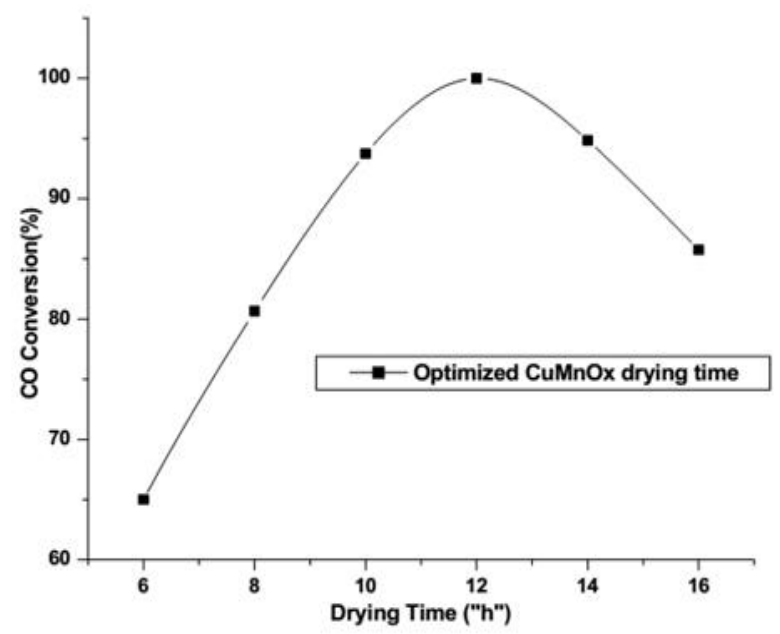

Figure 10. The optimization in the drying time of $\mathrm{CuMnO}_{\mathrm{x}}\left(\mathrm{CuMn}_{8}\right)$ precursor tion of stoichiometric $\mathrm{CuMnO}_{\mathrm{x}}$ catalyst $[37,38]$. 3.2.6 Effects of calcination time

The calcination processes produce a series of less crystalline or amorphous catalyst systems with greater active surface areas. The long time calcinations process might destroy the porous nature of the materials; it causes the catalytic activity of the catalyst is decreased. The catalyst produced under the flowing air calcination conditions still displayed many of the crystalline phase's presence on the catalyst surfaces. On rising the calcination time at a fixed temperature $300{ }^{\circ} \mathrm{C}$, a loss of crystallinity has occurred within the catalyst taking on an amorphous composition [10].

To optimize the calcinations time of $\mathrm{CuMnO}_{\mathrm{x}}$ precursor, at a fixed temperature of $300{ }^{\circ} \mathrm{C}$ is shown in Figure 12. The calcination time periods of $1 \mathrm{~h} 30 \mathrm{~min}, 2 \mathrm{~h}, 2 \mathrm{~h} 30 \mathrm{~min}$, and $3 \mathrm{~h}$ were selected and the $\mathrm{CO}$ conversions achieved over these catalysts were $82,90,100$, 95 , and $85 \%$, respectively. After the catalytic activity test, we have found out that the optimum calcination period of $\mathrm{CuMnO}_{\mathrm{x}}$ catalyst is $2 \mathrm{~h}$ and further increasing calcination time period the activity is decreased [17]. It is highly evident from these results that the calcination step is performing an important role to producing active catalysts for $\mathrm{CO}$ oxidation. In the calcination process, the precursor is kept in air for $2 \mathrm{~h}$ at $300{ }^{\circ} \mathrm{C}$; therefore it creates the active catalyst for $\mathrm{CO}$ oxidation. When the calcination time period is raised more than $2 \mathrm{~h}$, therefore the number of active sites presence on the surface of the catalyst is blocked so that the ability of the catalyst for $\mathrm{CO}$ oxidation decreases.

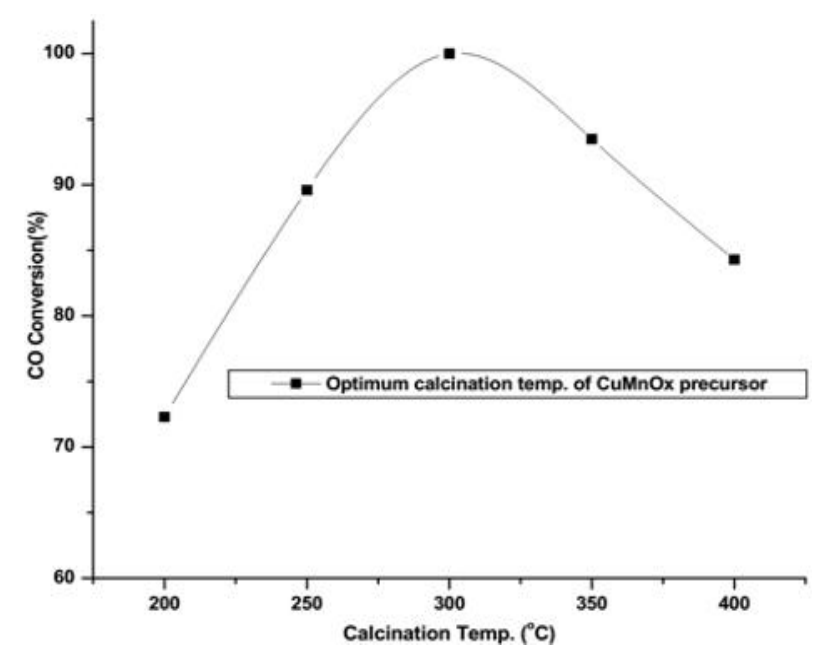

Figure 11. The optimization in calcination temperature of $\mathrm{CuMnO}_{\mathrm{x}}\left(\mathrm{CuMn}_{8}\right)$ precursor 


\subsubsection{Effects of the weight of catalyst}

The rate of $\mathrm{CO}$ oxidation is proportional to the weight of catalyst. In Figure 13, the weight of catalyst is varying from 50 to $160 \mathrm{mg}$ with the constant value of temperature and feed composition. In the catalytic reaction, the amount of catalyst is used for the $\mathrm{CO}$ oxidation reaction plays an essential role since the optimization of them can further improve the composition of the catalyst [10]. The external mass transfer did not limit the conversion rate when the temperature of the catalyst is raised; therefore the coverage of surfaces by $\mathrm{CO}$ oxidation will start to decreases. The rate of reaction between the adsorbed CO molecules and the oxygen atoms is relatively fast, even at ambient temperature [39].

The surface area, oxidation states, crystallinity which strongly influences on the catalytic properties and it can be controlled by changing the catalyst composition, metal concentration, additive concentration in the mother liquid, precipitation temperature, and calcination temperature, etc. [17]. All the reaction is carried out in the steady state conditions. The experiment is demonstrated as a higher catalyst weight leads to longer contact time, further, leads to a better catalytic performance. The CO conversions achieved over the different weight of catalysts like 50,75,100, 125 , and $150 \mathrm{mg}$ are $72,85,100,92$, and $80 \%$, respectively. After the catalytic activity test, we have found out that the optimum weight of catalyst is 100 $\mathrm{mg}$ and further increases the weight of catalyst the activity is decreased. It can be confirmed that the optimization of the process parameters

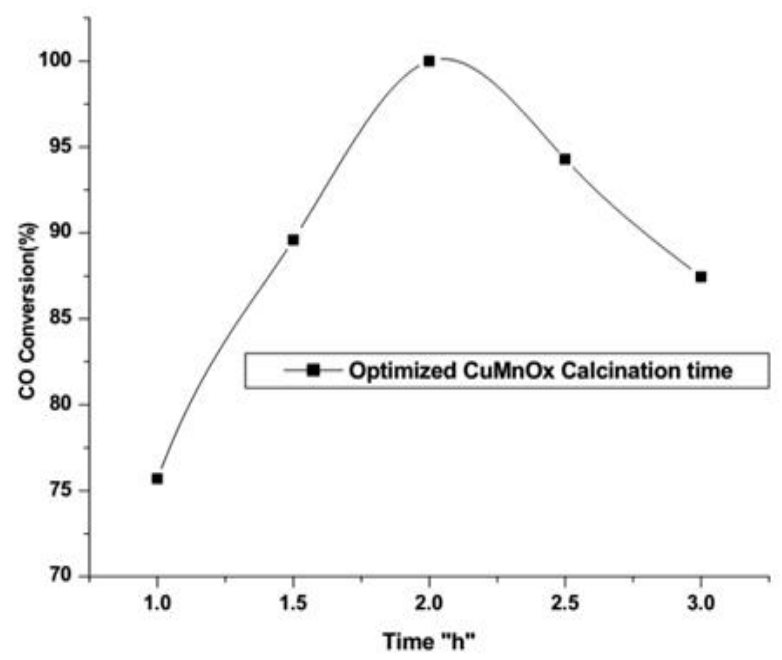

Figure 12. The optimization in calcination time of $\mathrm{CuMnO}_{\mathrm{x}}(\mathrm{CuMn} 8)$ catalyst for $\mathrm{CO}$ oxidation simultaneously improves catalyst performance for $\mathrm{CO}$ oxidation [14].

\subsubsection{Effects of different CO flow rate}

The binding energy of CO has depended upon the concentration of vacancies presence in a catalyst surfaces during steady-state conditions. The enthalpy of $\mathrm{CO}$ adsorption is represented the strongest contributor to the effects of temperature on effective $\mathrm{CO}$ oxidation rate constants [36,40]. In Figure 14, we have observed that the flow rate of $\mathrm{CO}$ is varying from 1.0 to $1.75 \mathrm{~mL} / \mathrm{min}$, and the optimum flow rate of $\mathrm{CO}$ for $\mathrm{CO}$ oxidation is $1.5 \mathrm{~mL} / \mathrm{min}$. The further increases the $\mathrm{CO}$ flow rate the activity of the catalyst is decreased. The different flow rates could results if the catalyst particles are packed at various densities, as this leads to various pressure drops over the catalyst bed [35].

At the higher temperature, the $\mathrm{CO}$ production is an increase due to the lattice oxygen is consumed with simultaneously $\mathrm{CO}$ oxidation. In the process of reactants, adsorption is considered as an exothermic process, while the products desorption is considered as an endothermic [28]. The increase oxidation rates are correlated with the appearance of a "reactive" CO species which existed in significant amounts only during intermittent operation [27]. The homogeneous nature of $\mathrm{CuMnO}_{\mathrm{x}}$ catalyst is an important factors effect on the high catalytic activity [12]. The $\mathrm{CO}$ oxidation rate enhancement is possible only if the surface is exposed to oxygen for a minimum period without any $\mathrm{CO}$ being present in the gas phase [32].

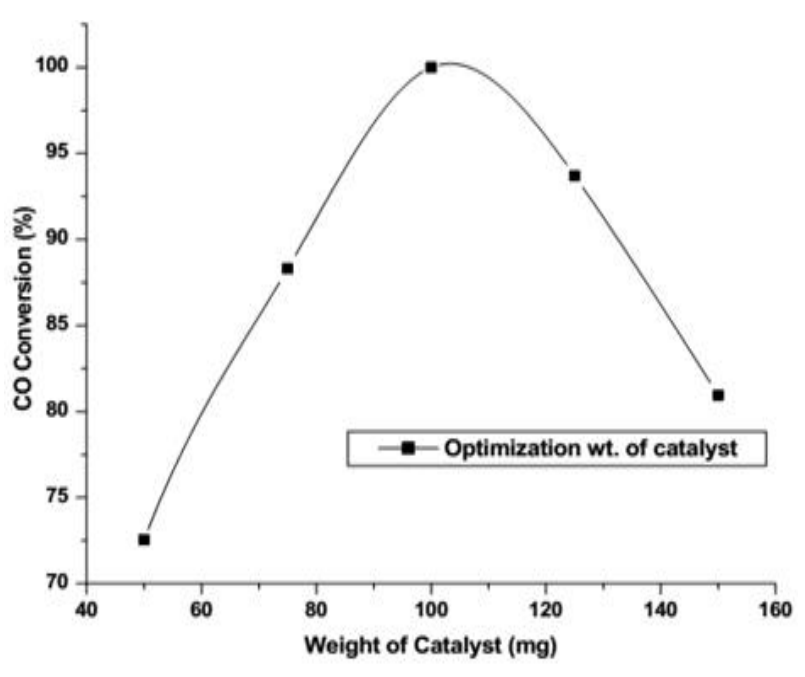

Figure 13. The optimization in weight of $\mathrm{CuMnO}_{\mathrm{x}}(\mathrm{CuMn} 8)$ catalyst for $\mathrm{CO}$ oxidation 


\subsection{Interpretation of treatment effect}

It is clear that the precipitation and calcination conditions have an important effect on the performance of $\mathrm{CuMnO}_{\mathrm{x}}$ catalyst for $\mathrm{CO}$ oxidation at low temperature. In Table 4, we have mentioned that the optimum preparation parameters and the experimental conditions of $\mathrm{CuMnO}_{\mathrm{x}}$ catalyst. In this study, the optimum molar ratio of $(\mathrm{Cu}: \mathrm{Mn})$ in $\mathrm{CuMnO}_{\mathrm{x}}$ catalyst was $(1: 8)$ and this ratio same as the previous paper results, i.e. Njagi et al. [10], examined the results the catalytic activity maxima for $\mathrm{CuMnO}_{\mathrm{x}}$ catalysts at a (Cu:Mn) molar ratio of 10/80.

In the activity test, we have observed that the increasing drying temperature and time of $\mathrm{CuMnO}_{\mathrm{x}}$ catalyst beyond their optimum drying temperature, the activity was decreased. In this test, the optimum drying temperature and time of $\mathrm{CuMnO}_{\mathrm{x}}$ precursor was $110{ }^{\circ} \mathrm{C}$ for $12 \mathrm{~h}$. According to Hutchings et al. [17] and Mirzaei et al. [28] the optimum drying temperature and time of $\mathrm{CuMnO}_{\mathrm{x}}$ precursor was $120{ }^{\circ} \mathrm{C}$ for $16 \mathrm{~h}$ and $80{ }^{\circ} \mathrm{C}$ for $24 \mathrm{~h}$, respectively. The calcination

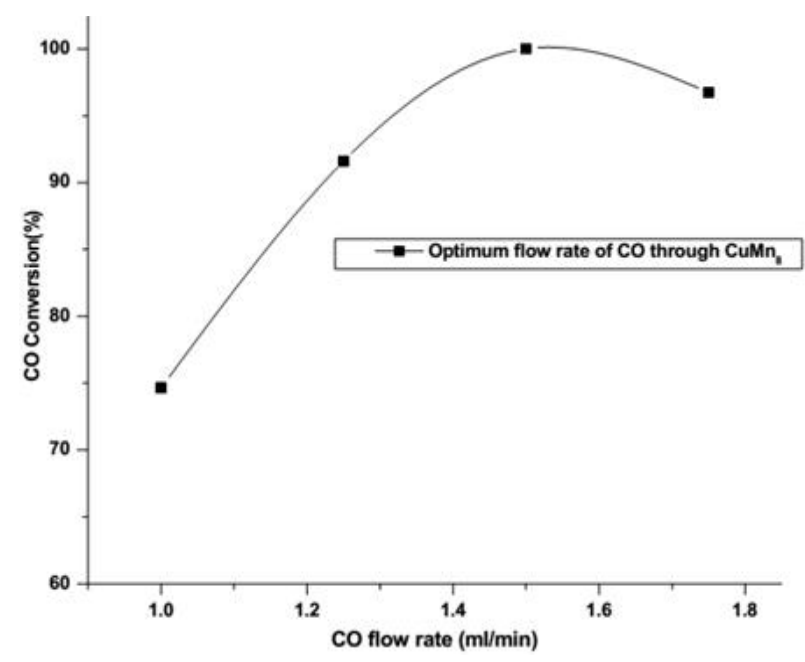

Figure 13. The optimum flow rate of $\mathrm{CO}$ in the $\mathrm{CuMnO}_{\mathrm{x}}\left(\mathrm{CuMn}_{8}\right)$ catalyst for $\mathrm{CO}$ oxidation temperature also influences the activity of the resulting catalyst for $\mathrm{CO}$ oxidation. According to Solsona et al. [38], the $\mathrm{CuMnO}_{\mathrm{x}}$ catalyst calcined at $200{ }^{\circ} \mathrm{C}$ were considerably more amorphous and no crystalline phase could be clearly identified. The crystallinity of the catalyst increases as the calcination temperature increases and when more crystalline catalysts produced by calcination at 400 to $500{ }^{\circ} \mathrm{C}$ with the optimum calcination temperature and time of $\mathrm{CuMnO}_{\mathrm{x}}$ catalyst was $300{ }^{\circ} \mathrm{C}$ at $2 \mathrm{~h}$ respectively. From the previous study [17], we observed the importance of calcination temperature and time with respect to catalyst activity. According to Njagi et al. [10], the optimum calcination temperature of $\mathrm{CuMnO}_{\mathrm{x}}$ catalyst was $300{ }^{\circ} \mathrm{C}$ and it is same as the present experimental results. Hutchings et al. [17] have reported that high-temperature calcinations of $\mathrm{CuMnO}_{\mathrm{x}}$ precursor were deleterious to catalytic activity. When we compare our experimental results of optimum calcination time of $\mathrm{CuMnO}_{\mathrm{x}}$ catalyst with the previous research report $[10,12]$, we have found out that $2 \mathrm{~h}$ is the optimum time for calcination.

In the activity test, we have checked that the optimum flow rate of $\mathrm{CO}$ was $1.5 \mathrm{~mL} / \mathrm{min}$ and further increase or decrease the $\mathrm{CO}$ flow rate the activity of catalyst decreases. According to Njagi et al. [10], Solsona et al. [38], Mirzaei et al. [28], and Cai et al. [19] the optimum flow rate of $\mathrm{CO}$ was $1 \mathrm{~mL} / \mathrm{min}, 1 \mathrm{~mL} / \mathrm{min}$, $5 \mathrm{~mL} / \mathrm{min}$, and $1 \mathrm{~mL} / \mathrm{min}$, respectively. Hutchings et al. [17] and Kramer et al. [18] also found out that the optimum flow rate of $\mathrm{CO}$ in the $\mathrm{CO}$ oxidation process is $5 \mathrm{~mL} / \mathrm{min}$ and $0.25 \mathrm{~mL} / \mathrm{min}$, respectively. The optimum weight of catalyst presence in the reactor also influences their activity for $\mathrm{CO}$ oxidation. Hutchings et al. [17] and Solsona et al. [38] have investigated that the optimum weight of the catalyst for CO oxidation was $100 \mathrm{mg}$ [40]. In this study, we have found out that the opti-

Table 4. The optimum preparation conditions of $\mathrm{CuMnO}_{\mathrm{x}}$ catalyst

\begin{tabular}{cc}
\hline Parameters & Optimization \\
\hline (Cu:Mn) ratio & $1: 8$ \\
Drying temperature $\left({ }^{\circ} \mathrm{C}\right)$ & 110 \\
Drying time $(\mathrm{h})$ & 12 \\
Calcination temperature $\left({ }^{\circ} \mathrm{C}\right)$ & 300 \\
Calcination time $(\mathrm{h})$ & 2 \\
Particle size $(\mu($ micron$))$ & 60 \\
Weight of catalyst $(\mathrm{mg})$ & 100 \\
CO flow rate $(\mathrm{mL} / \mathrm{min})$ & 1.5 \\
\hline
\end{tabular}


mum weight of the catalyst is $100 \mathrm{mg}$ and further increase or decrease the weight of the catalyst; therefore the activity of the catalyst for $\mathrm{CO}$ oxidation decreases. In this way, we have benchmarked the performance of $\mathrm{CuMnO}_{\mathrm{x}}$ catalyst with the previously reported works.

\section{Conclusions}

Many factors which can be varied during the catalyst prepared by co-precipitation method and the subsequent calcination steps are important in controlling the activity of $\mathrm{CuMnO}_{\mathrm{x}}$ catalysts for low-temperature $\mathrm{CO}$ oxidation. The preparation conditions of $\mathrm{CuMnO}_{\mathrm{x}}$ catalyst for getting excellent catalytic activity are 1/8 (Cu:Mn) ratio at $110{ }^{\circ} \mathrm{C}$ drying temperature for $12 \mathrm{~h}$, followed by calcination at $300{ }^{\circ} \mathrm{C}$ for $2 \mathrm{~h}$. The optimum operating parameters for $\mathrm{CO}$ oxidation are the $100 \mathrm{mg}$ weight of catalyst at a flow rate of $\mathrm{CO}(1.5 \mathrm{~mL} / \mathrm{min})$ with the optimum particle size is $60 \mu \mathrm{m}$ (micron) used. However, the results presented in this study, clear that the precipitation and calcination conditions are applied in the preparation procedure are crucial importance.

In particular, the catalyst drying and calcination conditions have found to be the most significance and control of these parameters should be incorporated into the design of experimental programmed. In the catalytic $\mathrm{CO}$ oxidation, process the $\mathrm{O}_{2}$ plays a major role in two different ways. In the first $\mathrm{O}_{2}$ molecules may react immediately with $\mathrm{CO}$ reduction products of the catalysts thus regaining the initial composition, therefore, these are get activated for a catalytic oxidation of $\mathrm{CO}$ molecules thus eliminating them from the gas atmosphere. The extraordinary performance of $\mathrm{CuMnO}_{\mathrm{x}}$ catalyst prepared by flowing air calcination conditions for $\mathrm{CO}$ oxidation is associated with the modification in inherent textural and morphological characteristics such as surface area, crystallite size, particle size, and oxygen deficient faulty composition which creates the high density of active sites.

\section{References}

[1] Blumenthal, I. (2001). Carbon Monoxide Poisoning. Journal of the Royal Society of Medicine, 94: 270-272.

[2] Rattan, G., Prasad, R., Katyal, R.C. (2012). Effect of Preparation Methods on $\mathrm{Al}_{2} \mathrm{O}_{3}$ Supported $\mathrm{CuO}-\mathrm{CeO}_{2}-\mathrm{ZrO}_{2}$ Catalysts for $\mathrm{CO}$ Oxidation. Bulletin of Chemical Reaction Engineering \& Catalysis, 7(2): 112-123.
[3] Touger, M., Gallagher, E.J., Tyrrel, J. (1995). Relationship between Venous and Arterial Carboxy-Hemoglobin Levels in Patients with Suspected Carbon Monoxide Poisoning. Journal of Annals Emergency Medicine, 25: 481483.

[4] Taylor, S.H., Rhodes, C. (2005). Ambient Temperature Oxidation of Carbon Monoxide Using a $\mathrm{Cu}_{2} \mathrm{Ag}_{2} \mathrm{O}_{3}$ Catalyst. Catalysis Letter, 101: 31-33.

[5] Badr, O., Probert, S.D. (1994). Carbon Monoxide Concentration in the Earth's Atmosphere. Applied Energy, 49: 99-143.

[6] Pardiwala, J.M., Patel, F., Patel, S. (2011), Review Paper on Catalytic Converter for Automotive Exhaust Emission, International Conference on Current Trends in Technology, Nuicone, 08-10.

[7] Tanaka, Y., Utaka, T., Kikuchi, R., Takeguchi, T., Sasaki, K., Eguchi K. (2003). Water Gas Shift Reaction for the Reformed Fuels over $\mathrm{Cu} / \mathrm{MnO}$ Catalysts Prepared via SpinelType Oxide. Journal of Catalysis, 215: 271278.

[8] Du, P., Wang, W., Jia, C., Song, Q., Huang, Y., Si, R. (2016). Effect of Strongly Bound Copper Species in Copper-Ceria Catalyst for Preferential Oxidation of Carbon Monoxide. Applied Catalysis A: General, 518: 87-101.

[9] Mishra, A., Prasad, R. (2011). A Review on Preferential Oxidation of Carbon Monoxide in Hydrogen Rich Gases. Bulletin of Chemical Reaction Engineering \& Catalysis, 6(1): 1-14.

[10] Njagi, E.C., Chen, C., Genuino, H., Galindo, H., Huang, H., Suib, S.L. (2010), Total Oxidation of $\mathrm{CO}$ at Ambient Temperature Using Copper Manganese Oxide Catalysts Prepared by a Redox Method. Applied Catalysis B: Environmental, 99: 103-110.

[11] Schwab, G.M., Kanungo, S.B. (1977). Efficient Stable Catalyst for Low-Temperature Carbon Monoxide Oxidation. Journal of $\mathrm{Ca}$ talysis, 107: 109-120.

[12] Hasegawa, Y., Maki, R., Sano, M., Miyake, T., (2009). Preferential Oxidation of CO on Copper-Containing Manganese Oxides. Applied Catalysis A: General, 371: 67-72.

[13] Narasimharao, K., Al-Shehi, A., Al-Thabaiti, S. (2015). Porous Ag- $\mathrm{Fe}_{2} \mathrm{O}_{3}$ Nano Composite Catalysts for the Oxidation of Carbon Monoxide. Applied Catalysis A: General, 505: 431440.

[14] Qian, K., Qian, Z., Hua, Q., Jiang, Z., Huang, W. (2013). Structure Activity Relationship of $\mathrm{CuO} / \mathrm{MnO}_{2}$ Catalysts in $\mathrm{CO}$ Oxidation. Applied Surface Science, 273: 357-363. 
[15] Tang, Z.R., Jones, C.D., Aldridge, J.K.W., Davies, T.E., Bartley, J.K., Carley, A.F., Taylor, S.H., Allix, M., Dickinson, C., Rosseinsky, M.J., Claridge, J.B., Xu, Z., Crudace, M.J., Hutchings, G.J. (2009). New Nanocrystalline $\mathrm{Cu} / \mathrm{MnO}_{\mathrm{x}}$ Catalysts Prepared from Supercritical Anti Solvent Precipitation. Chem. Cat. Chem. Catal., 2: 247-251.

[16] Hoskins, W.M., Bray, W.C. (1926). The Catalytic Oxidation of Carbon Monoxide and the Adsorption of Carbon Dioxide, Carbon Monoxide and Oxygen by the Catalysts, Manganese Dioxide, Cupric Oxide and Mixture of These Oxides. Journal of American Chemical Society, 48: 1454-1474.

[17] Hutchings, G.J., Mirzaei, A.A., Joyner, R.W., Siddiqui, M.R.H., Taylor, S.H. (1997). Effect of Preparation Conditions on Catalytic Performance of Copper Manganese Oxide Catalysts for CO Oxidation. Applied Catalysis A: General, 166: 143-152.

[18] Kramer, M., Schmidt, T., Stowe, K., Maier, W.F. (2006), Structural and Catalytic Aspects of Sol-Gel Derived Copper Manganese Oxides as Low-Temperature CO Oxidation Catalyst. Applied Catalysis A: General, 302: 257-263.

[19] Cai, L., Guo, Y., Lu, A., Branton, P., Li, W. (2012). The Choice of Precipitant and Precursor in the Co-Precipitation Synthesis of Copper Manganese Oxide for Maximizing Carbon Monoxide Oxidation. Journal of Molecular Catalysis A: Chemical, 360: 35-41.

[20] Wojciechowska, M., Przystajko, W., Zielinski M. (2007). CO Oxidation Catalysts Based on Copper and Manganese or Cobalt Oxides Supported on $\mathrm{MgF}_{2}$ and $\mathrm{Al}_{2} \mathrm{O}_{3}$. Catalysis Today, 119: 338-341.

[21] Shi, L., Hu, Z., Deng, G., Li, W. (2015). Carbon Monoxide Oxidation on Copper Manganese Oxides Prepared by Selective Etching with Ammonia. Chinese Journal of Catalysis, 36: 1920-1927.

[22] Biemelt, T., Wegner, K., Trichert, J., Lohe, M.R., Martin, J., Grothe, J., Kaskel, S. (2015). Hopcalite Nanoparticle Catalysts with High Water Vapour Stability for Catalytic Oxidation of Carbon Monoxide. Applied Catalysis B: Environmental, 21: 1-26.

[23] Clarke, T.J., Davies, T.E., Kondrat, S.A., Taylor, S.H. (2015). Mechano Chemical Synthesis of Copper Manganese Oxide for the Ambient Temperature Oxidation of Carbon Monoxide. Applied Catalysis B: Environmental, 165: 222231.

[24] Arango-Diaz, A., Cecilia, J.A., Santos-Gomez, L., Marrero-Lopez, D., Losilla, E.R., JimenezJimenez, J., Rodriguez-Castellon, E. (2015). Characterization and Performance in Preferential Oxidation of $\mathrm{CO}$ of $\mathrm{CuO}-\mathrm{CeO}_{2}$ Catalysts
Synthesized Using Polymethyl Metacrylate (PMMA) as Template. International Journal of Hydrogen Energy, 40: 11254-11260.

[25] Lee, J., Kim, H., Lee, H., Jang, S., Chang, J.H. (2016). Highly Efficient Elimination of Carbon Monoxide with Binary CopperManganese Oxide Contained Ordered Nanoporous Silicas. Nanoscale Research Letter, 11(6): 1-6.

[26] Jones, C., Cole, K.J., Taylor, S.H., Crudace, M.J., Hutchings, G.J. (2009). Copper Manganese Oxide Catalysts for Ambient Temperature Carbon Monoxide Oxidation: Effect of Calcination on Activity. Journal of Molecular Catalysis A: Chemical, 305: 121-124.

[27] Kondrat, S.A., Davies, T.E., Zu, Z., Boldrin, P., Bartley, J.K., Carley, A.F., Taylor, S.H., Rosseinsky, M.J., Hutchings, G.J. (2011). The Effect of Heat Treatment on Phase Formation of Copper Manganese Oxide: Influence on Catalytic Activity for Ambient Temperature Carbon Monoxide Oxidation. Journal of $\mathrm{Ca}$ talysis, 281: 279-289.

[28] Mirzaei, A.A., Shaterian, R.H., Habibi, M., Hutchings, G.J., Taylor, S.H. (2003). Characterization of Copper-Manganese Oxide Catalysts: Effect of Precipitate Ageing upon the Structure and Morphology of Precursors and Catalysts. Applied Catalysis A: General, 253: 499-508.

[29] Irawan, R.M.B., Purwanto, P., Hadiyanto, H. (2015). Optimum Design of Manganese Coated Copper Catalytic Converter to Reduce Carbon Monoxide Emissions on Gasoline Motor. Journal of Environmental Sciences, 23: 86-92.

[30] Snytnikov, P.V., Popova, M.M., Men, Y., Rebrov, E.V., Kolb, G., Hessel, V., Schouten, J.C., Sobyanin, V.A. (2008). Preferential CO Oxidation over a Copper-Cerium Oxide Catalyst in a Micro Channel Reactor. Applied $\mathrm{Ca}$ talysis A: General, 350: 53-62.

[31] Dey, S., Dhal, G. C., Prasad, R., Mohan, D. (2016). The Effect of Doping on the Catalytic Activity of $\mathrm{CuMnO}_{\mathrm{x}}$ Catalyst for CO Oxidation. Journal of Environmental Science, Toxicology and Food Technology, 10(11): 86-94.

[32] Li, M., Wang, D., Shi, X., Zhang, Z., Dong, T. (2007). Kinetics of Catalytic Oxidation of CO over Copper-Manganese Oxide Catalyst. Separation and Purification Technology, 57: 147-151.

[33] Meiyi, G., Nan, J., Yuhong, Z., Changjin, X., Haiquan, S., Shanghong, Z. (2016). Coppercerium Oxides Supported on Carbon Nonmaterial for Preferential Oxidation of Carbon Monoxide. Journal of Rare Earths, 34: 55-60. 
[34] Cole, K.J., Carley, A.F., Crudace, M.J., Clarke, M., Taylor, S.H., Hutchings, G.J. (2010). Copper Manganese Oxide Catalysts Modified by Gold Deposition: The Influence on Activity for Ambient Temperature Carbon Monoxide Oxidation. Catalysis Letters, 138: 143-147.

[35] Prasad, R., Singh, P. (2013). A Novel Route of Single Step Reactive Calcination of Copper Salts Far below their Decomposition Temperatures for Synthesis of Highly Active Catalysts. RSC Publishing: Catalysis Science and Technology, 3: 3326-3334.

[36] Hasegawa, Y., Fukumoto, K., Ishima, T., Yamamoto, H., Sano, M., Miyake, T. (2009). Preparation of Copper Containing Mesoporous Manganese Oxides and their Catalytic Performance for CO Oxidation. Applied Catalysis B: Environmental, 89: 420-424.

[37] Tang, Z.R., Kondrat, S.A., Dickinson, C., Bartley, J.K., Carley, A.F., Taylor, S.H., Davies, T.E., Allix, M., Rosseinsky, M. J., Claridge, J.B., Xu, Z., Romani, S., Crudace, M.J., Hutching, G.J. (2011). Synthesis of High
Surface Area $\mathrm{CuMn}_{2} \mathrm{O}_{4}$ by Supercritical AntiSolvent Precipitation for the Oxidation of CO at Ambient Temperature. Journal of Royal Society of Chemistry, 1: 740-746.

[38] Solsona, B., Hutchings, G.J., Garcia, T., Taylor, S.H. (2004), Improvement of the Catalytic Performance of CuMnOx Catalysts for $\mathrm{CO}$ Oxidation by the Addition of Au. New Journal of Chemistry, 28: 708-711.

[39] Xia, G.G., Yin, Y.G., Willis, W.S., Wang, J.Y., Suib, S.L. (1999). Efficient Stable Catalysts for Low Temperature Carbon Monoxide Oxidation. Journal of Catalysis, 185: 91-105.

[40] Wang, J., Chernavskii, P.A., Wang, Y., Khodakov, A.Y. (2013). Influence of the Support and Promotion on the Structure and Catalytic Performance of Copper-Cobalt Catalysts for Carbon Monoxide Hydrogenation. Journal of Fuel, 103: 1111-1122. 